\title{
Luigi Tomba ed., East Asian Capitalism. Conflicts, Growth and Crisis
}

Milan, Feltrinelli, 2002, 523 p.

\section{Gilles Guiheux}

\section{(Q) OpenEdition}

\section{Journals}

Édition électronique

URL : http://journals.openedition.org/chinaperspectives/797

DOI : $10.4000 /$ chinaperspectives.797

ISSN : 1996-4617

\section{Éditeur}

Centre d'étude français sur la Chine contemporaine

Édition imprimée

Date de publication : 1 février 2004

ISSN : 2070-3449

\section{Référence électronique}

Gilles Guiheux, « Luigi Tomba ed., East Asian Capitalism. Conflicts, Growth and Crisis », China

Perspectives [En ligne], 51 | january-february 2004, mis en ligne le 23 avril 2007, consulté le 21 septembre 2020. URL : http://journals.openedition.org/chinaperspectives/797 ; DOI : https://doi.org/ 10.4000/chinaperspectives.797

Ce document a été généré automatiquement le 21 septembre 2020

(c) All rights reserved 


\title{
Luigi Tomba ed., East Asian Capitalism. Conflicts, Growth and Crisis
}

\author{
Milan, Feltrinelli, 2002, 523 p.
}

\author{
Gilles Guiheux
}

\section{NOTE DE L'ÉDITEUR}

Translated from the French original by Philip Liddell

1 This book brings together some of the contributions made to a conference held in Cortona, Italy, in 2001. The writers come from a variety of academic backgrounds; they are economists, sociologists, historians, anthropologists and political scientists. Some articles focus on a single country-be it Indonesia or Japan-while others are transnational and comparative. All share the same perspective, clearly laid down by the preface. In it, Luigi Tomba draws up the balance sheet of the theoretical debates raised by economic growth in East Asia over the past thirty years. This publication aims to place the trajectory of development within a new perspective, both historical and political. Growth, Tomba writes, is not the fruit of rational decisions taken by the political authorities, far from it. His perspective, and any evaluation of the future possibilities for development, requires that growth be understood within the context of political conflict and the struggle for power between groups with divergent interests. The contributors then take up the task, each on his own behalf, starting from this firm sociological foundation, which consists in seeing institutions within processes of conflict, of confrontations and negotiations, out of which the politics of growth have been engendered.

2 The various contributions have been arranged in three big sections. The first describes the changing frontiers of political action, under the pressure of economic changes, reforms and globalisation. The second is focused on the negotiation processes, which 
lead onwards to the definition of the politics of development. The final section deals with conflicts-class conflicts and other kinds of conflict too-which divide societies and contribute to defining them.

3 On China, we find familiar analyses. Tony Saich goes back over the transformation of the state and over the development of relations between central state and local state. Takwing Ngo compares the nature of political power in the People's Republic, Taiwan and Hong Kong. Jean-François Huchet looks at the evolution of enterprise management in the context of the political system. Dorothy Solinger looks back over the changing relations between the Communist Party and the workers. Hein Mallee analyses the crisis of the hukou system.

4 The relevance of the intellectual project and the quality of the editorial work make this publication a useful work of reference for anyone seeking to put into perspective the development of East Asia as a whole. Unlike any discourse centred on a supposed "Asian model", each contribution emphasises the differences between countries and the originality of their local contexts. 